\title{
EFFECT OF SUGAMMADEX AND NEOSTIGMINE ON BLOOD GLUCOSE LEVEL: A PROSPECTIVE RANDOMIZED CONTROLLED TRIAL
}

\author{
Yazar Akif Mehmet, ${ }^{1}$ Balaban Onur, ${ }^{2}$ Yoldas Kuvvet Tuba, ${ }^{3}$ Sarıkus Zehra ${ }^{4}$ \\ ${ }^{1}$ Konya Training and Research Hospital, Department of Anesthesiology, Konya, Turkey \\ ${ }^{2}$ Dumlupinar University, Department of Anesthesiology \& Pain Medicine, Kutahya, Turkey \\ ${ }^{3}$ Ege University, Department of Anesthesiology, Izmir, Turkey \\ ${ }^{4}$ Nevsehir Public Hospital, Department of Anesthesiology, Nevsehir, Turkey
}

Primljen/Received 30. 09. 2018. god.

\begin{abstract}
Objectives: Sugammadex is offered as a recent alternative to cholinesterase inhibitors in reversing neuromuscular block. Sugammadex is a cyclodextrin molecule that is consisted of bounded sugar molecules. Given its chemical structure, sugammadex may increase blood glucose levels. We aimed to investigate the effect of sugammadex on blood glucose and compare sugammadex to the conventional reverse agent Neostigmine. Methods: Sixty patients undergoing abdominal surgery under general anesthesia were included in this study. The patients were randomly divided into two groups: Group N ( $=30)$ and Group S $(n=30)$. At the end of the surgery $50 \mu \mathrm{g} / \mathrm{kg}$ Neostigmine and $20 \mu \mathrm{g} / \mathrm{kg}$ atropine was administered for the patients in Group $\mathrm{N}$ and 2 $\mathrm{mg} / \mathrm{kg}$ sugammadex was administered for the patients in Group S. Blood glucose levels were measured at $15 \mathrm{mi}-$ nutes before (T1) and at $30^{\text {th }}$ minute of surgery (T2). Blood glucose levels were recorded 30 minutes (T3), 2 hours (T4) and 4 hours (T5) after administration of the reversing agent. Results: Blood glucose levels that were measured at T3, T4 and T5 were significantly higher in Group S compared to Group N ( $<<0.05)$. We consider that sugammadex contains glucose molecules and does not bind to plasma proteins, may cause an increase in blood glucose level and this increase may be associated with chemical structure of sugammadex rather than surgical stress.
\end{abstract}

Key words: Neuromuscular block reverse, $\mathrm{Su}-$ gammadex, Neostigmine, blood glucose level.

\section{INTRODUCTION}

Blood glucose level effects mortality and morbidity in the perioperative period. Surgical stimulus is
Prihvaćen/Accepted 29. 11. 2018. god.

among the most important factors that affect the metabolic and endocrine system response during surgery. Blood glucose level is increased by surgical stimulus that influences insulin and glucagon release. Increase in blood glucose levels is a factor that directly effects wound healing negatively and may prolong length of hospital stay $(1,2)$. Neuromuscular blocking agents are frequently used in general anesthesia in order to facilitate endotracheal intubation and provide muscle relaxation during the surgery. Non-depolari- zing neuromuscular blockers, which are also known as muscle relaxants, block the binding of neurotransmitters to nicotinic acetylcholine receptor at the neuromuscular junction of motor neurons and paralyze the muscles. Cholinesterase inhibitors such as neostigmine are the most commonly used agents in anesthesiology practice to reverse effects of non-depolarizing neuromuscular blockers. Neostigmine provides acetylcholine accumulation in neuromuscular junction by inhibiting acetyl-cholin-esterase. This promotes neuromuscular transmission in the synapse and helps return of normal muscle function $(3,4,5)$.

Sugammadex is an excellent alternative to the conventional decurarisation process performed with cholinesterase inhibitors. Sugammadex reverses deep rocuronium-induced neuromuscular block safely and rapidly without resulting in anticholinergic side effects. Sugammadex ensures elimination of non-depolarizing muscle relaxants such as rocuronium and vecuronium via the kidneys without being metabolized $(6,7,8)$. Sugammadex is a modified gamma-cyclodextrin which makes steroidal non-depolarizing muscle relaxants inactive by encapsulating them. Gamma-cyclodextrin is consisted 
of eight glucose units. "Su" refers to sugar and "gammadex" refers to the structural molecule gamma-cyclodextrin $(9,10)$.

Our hypothesis was sugammadex might increase blood glucose levels given its chemical structure. We aimed to assess the effect of sugammadex on blood glucose and compare sugammadex to the conventional reverse agent Neostigmine.

\section{MATERIAL AND METHODS}

This study is designed as a prospective, randomized, controlled clinical research. It was approved by Clinical Research Ethics Committee of Kocaeli University. Written informed consents have been obtained from all patients that participated in the study. We enrolled 60 patients, aged between 18-65 years with American Society of Anesthesiologists (ASA) class I-II-III who were planned to undergo abdominal surgery under general anesthesia. The patients who had diabetes mellitus and other endocrine diseases (such as hyperthyroidism, hypothyroidism, renal-hepatic enzyme disorders, pregnancy and lactation) causing abnormal glucose metabolism or the patients using drugs (such as steroids, beta-blockers, insulin, sulfonylurea) which may effects glucose metabolism and patients who had alcohol usage in the past week were excluded from the study. The patients were randomized into two groups using a computerized randomization program. Thirty patients were included in the Neostigmine group (Group N) and 30 patients were included in the sugammadex group (Group $\mathrm{S}$ ).

All patients were held nil per os for 8 hours. After cannulation with 18-20 Gauge intravenous catheter, infusion of $0.9 \%$ normal saline was started. The patients did not receive any glucose-containing intravenous fluids and were not fed during the first 4 hours of the postoperative period. The patients were premedicated with $0.03 \mathrm{mg} / \mathrm{kg}$ midazolam and $1 \mu \mathrm{g} / \mathrm{kg}$ fentanyl before the surgery. Electrocardiography (ECG), heart rate (HR), non-invasive measurement of systolic arterial pressure (SAP), diastolic arterial pressure (DAP), mean arterial blood pressure (MAP), pulse oxymetry $(\mathrm{SpO} 2)$, and end-tidal carbon dioxide pressure (Et$\mathrm{CO} 2$ ) was monitored in the operating room. A train of four (TOF) device (Watch S, Organon) was used to measure the level of neuromuscular block.

For anesthesia induction, $5 \mathrm{mg} / \mathrm{kg}$ intravenous sodium thiopental, was administered to all patients. Muscle relaxation was achieved using $0.6 \mathrm{mg} / \mathrm{kg}$ intravenous rocuronium bromide. When maximum neuromuscular block occurred (TOF ratio $=0.0$ ), the patient was intubated. The maintenance course of anesthesia was continued with intravenous infusion of $0.05 \mu \mathrm{g} / \mathrm{kg} / \mathrm{min}$ remifentanil and inhalation of $2 \%$ sevoflurane in a mixture of $50 \%$ Oxygen and $50 \%$ Nitrous oxide. All patients received $1 \mathrm{mg} / \mathrm{kg}$ of dexketoprofen for postoperative analgesia, 30 minutes before the end of the surgery. After the surgery was completed, $50 \mu \mathrm{g} / \mathrm{kg}$ of neostigmine and $20 \mu \mathrm{g} / \mathrm{kg}$ of atropine were given for the patients in Group N and $2 \mathrm{mg} / \mathrm{kg}$ of sugammadex in Group $\mathrm{S}$ to reverse the neuromuscular block of rocuronium. The patients were extubated after maximum muscle strength was achieved (TOF ratio $>0.9$ ).

The blood glucose levels of the patients were measured using a glucometer (Optium ${ }^{\circledR}$, Abbott laboratories, USA) with strip (Medisense ${ }^{\circledR}$, Abbott laboratories, UK). Blood glucose levels were measured 15 minutes preoperatively (T1) and at $30^{\text {th }}$ minute intraoperatively (T2). Blood glucose levels were also recorded 30 minutes (T3), 2 hours (T4) and 4 hours (T5) after the administration of reverse agents. SAP, DAP, MAP, HR, $\mathrm{SpO} 2, \mathrm{EtCO} 2$ were recorded at the same time. Duration of surgery was also recorded which was defined as: "The time measured starting from the first incision of the skin until the end of closing sutures of the skin."

Descriptive statistics (mean, standard deviation) were used to summarize data. Two-way analysis of variance (ANOVA) test was used for repeated measurements to find differences between the groups. Bonferroni paired t-test was used for paired comparisons within the groups. Independent sample t-test was used for the characteristics of the patients, and also Fisher's exact test was used for nominal values. Statistical significance was considered as $\mathrm{p}<0.05$ in the two-tailed tests.

\section{RESULTS}

There were no statistically significant difference between the groups in terms of gender, age, weight, duration of surgery, ASA, and comorbid diseases $(p>0.05)$ (Table 1). The distribution of types of surgery in two groups was stated in Table 2.

Table 1. The characteristics of the patients

\begin{tabular}{|l|c|c|c|}
\hline & $\begin{array}{c}\text { Sugammadex } \\
\text { Group } \\
\mathbf{( n = 3 0 )}\end{array}$ & $\begin{array}{c}\text { Neostigmine } \\
\text { Group } \\
\mathbf{( n = 3 0 )}\end{array}$ & P value \\
\hline Gender (Male/Female) & $11 / 19$ & $21 / 9$ & $0.70 *$ \\
\hline Age (years) & $56.13 \pm 8.38$ & $52.20 \pm 11.92$ & $0.14 * *$ \\
\hline Weight (kg) & $69.57 \pm 12.01$ & $69.47 \pm 12.71$ & $0.97 * *$ \\
\hline Duration of Surgery (min) & $106.50 \pm 31.89$ & $98.83 \pm 32.04$ & $0.35 * *$ \\
\hline ASA (I/II/III) & $6 / 13 / 11$ & $9 / 15 / 6$ & $0.12 *$ \\
\hline Comorbid Disease (Yes/No) & $22 / 8$ & $15 / 15$ & $0.06 *$ \\
\hline
\end{tabular}

p: The two-tailed significance test, ASA: The American Society of Anesthesiologists Anesthesia Risk Scoring

*The Fisher's exact test. **The independent sample t-test. 
Table 2. Types of surgery performed in two groups

\begin{tabular}{|l|c|c|}
\hline \multicolumn{1}{|c|}{ Types of surgery } & $\begin{array}{c}\text { Sugammadex } \\
\text { Group } \\
(\mathbf{n = 3 0 )}\end{array}$ & $\begin{array}{c}\text { Neostigmine } \\
\text { Group } \\
\text { (n= 30) }\end{array}$ \\
\hline $\begin{array}{l}\text { Total abdominal hysterectomy } \\
\text { and bilateral salpingooferectomy }\end{array}$ & 13 & 12 \\
\hline Excision of liver or pancreatic cysts & 1 & 2 \\
\hline Oophorectomy & 5 & 4 \\
\hline Exploration of abdominal masses & 2 & 1 \\
\hline Partial or total colectomy & 8 & 7 \\
\hline Partial or total gastrectomy & 1 & 2 \\
\hline Myomectomy & 0 & 2 \\
\hline
\end{tabular}

Table 3. The blood glucose levels ( $\mathrm{mg} / \mathrm{dL})$ in two groups

\begin{tabular}{|c|c|c|c|}
\hline & Sugammadex Group & Neostigmine group & $\mathbf{p}$ \\
\hline T1 & $105,77 \pm 20,29$ & $107,33 \pm 14,14$ & 0,742 \\
\hline T2 & $115,20 \pm 15,05$ & $111,87 \pm 17,66$ & 0,441 \\
\hline T3 & $146,20 \pm 30,67$ & $127,47 \pm 23,00$ & $0,008^{*}$ \\
\hline T4 & $143,03 \pm 29,01$ & $124,70 \pm 22,57$ & $0,007^{*}$ \\
\hline T5 & $141,37 \pm 31,19$ & $125,53 \pm 27,27$ & $0,034^{*}$ \\
\hline
\end{tabular}

T1: 15 minutes preoperatively; T2: 30 minutes intraoperatively; T3: 30 minutes after administration of the reversing agent; T4: 2 hours after administration of the reversing agent; T5: 4 hours after administration of the reversing agent. $* \mathrm{p}<0.05$

When the blood glucose levels were compared between the groups, there was no significant difference at $\mathrm{T} 1$ and $\mathrm{T} 2$ between the two groups. Blood glucose levels were significantly higher at T3, T4 and T5 in the Sugammadex group compared to those in Neostigmine group $(\mathrm{p}<0.05)$ (Figure 1). Blood glucose levels measured at T1, T2, T3, T4, T5 and $\mathrm{p}$ values in both groups

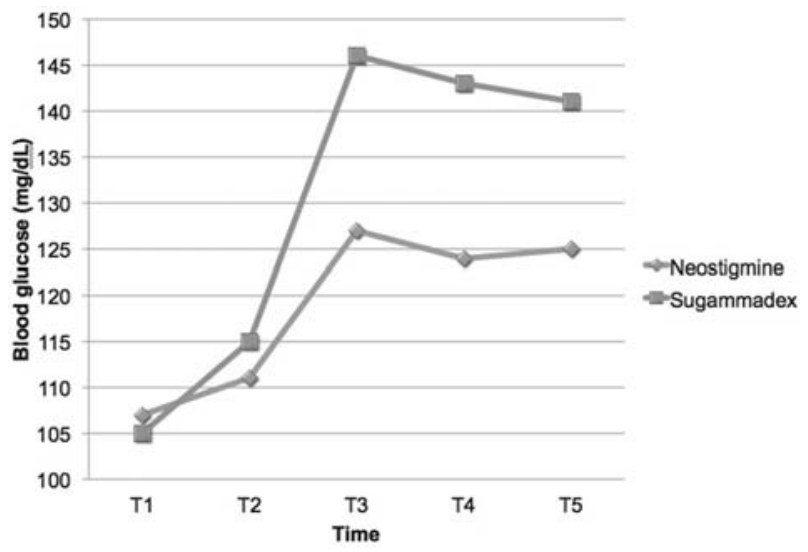

Figure 1. Graphical comparison of mean blood glucose levels ( $\mathrm{mg} / \mathrm{dL}$ ) in two groups. T1: 15 minutes preoperatively; T2: 30th minute intraoperatively; T3:

30 minutes after administration of the reversing agent; T4: 2 hours after administration of the reversing agent; T5: 4 hours after administration of the reversing agent

were shown in Table 3. Heart rate, non-invasive measurement of systolic arterial pressure, diastolic arterial pressure, mean arterial blood pressure, oxygen saturation and end-tidal carbon dioxide pressure values were shown in Table 4.

\section{DISCUSSION}

The current study compared the effect of sugammadex on blood glucose levels to neostigmine in patients who underwent abdominal surgery. We determined a significant increase in glucose levels when sugammadex was used. Efficacy and safety of sugammadex was excessively studied before, but to our knowledge, there is no study showing the effect of sugammadex on perioperative blood glucose levels (11).

Table 4. The hemodynamic values measured in two groups

\begin{tabular}{|c|c|c|c|c|c|c|}
\hline \multicolumn{2}{|c|}{} & T1 & T2 & T3 & T4 & T5 \\
\hline \multirow{2}{*}{ SAP $(\mathrm{mm} / \mathrm{Hg})$ mean \pm SD } & Group S & $143.0 \pm 23.59$ & $120.57 \pm 18.35$ & $133.33 \pm 22.74$ & $138.47 \pm 26.72$ & $134.43 \pm 24.09^{*}$ \\
\cline { 2 - 7 } & Group N & $136.47 \pm 26.85$ & $126.73 \pm 17.68$ & $141.0 \pm 18.95$ & $123.23 \pm 17.04$ & $115.87 \pm 17.16^{*}$ \\
\hline \multirow{2}{*}{ DAP (mm/Hg) mean \pm SD } & Group S & $83.07 \pm 16.97$ & $69.77 \pm 14.71$ & $75.13 \pm 12.33$ & $78.73 \pm 9.57$ & $74.03 \pm 8.63^{*}$ \\
\cline { 2 - 7 } & Group N & $77.93 \pm 10.63$ & $74.5 \pm 13.59$ & $79.67 \pm 13.35$ & $74.0 \pm 13.25$ & $68.57 \pm 11.23^{*}$ \\
\hline \multirow{2}{*}{ MAP (mm/Hg) mean \pm SD } & Group S & $103.83 \pm 21.91$ & $87.23 \pm 16.0$ & $93.2 \pm 13.45$ & $98.63 \pm 9.49$ & $95.0 \pm 10.32^{*}$ \\
\cline { 2 - 7 } & Group N & $98.2 \pm 17.27$ & $88.6 \pm 14.28$ & $104.13 \pm 14.59$ & $91.37 \pm 14.61$ & $84.13 \pm 12.35^{*}$ \\
\hline \multirow{2}{*}{ HR (beat/min) mean \pm SD } & Group S & $89.7 \pm 17.14$ & $82.73 \pm 17.35$ & $87.3 \pm 15.27$ & $90.53 \pm 14.02$ & $90.7 \pm 14.33$ \\
\cline { 2 - 7 } & Group N & $87.6 \pm 14.71$ & $77.67 \pm 10.99$ & $83.6 \pm 19.12$ & $80.17 \pm 18.48$ & $87.87 \pm 17.77$ \\
\hline
\end{tabular}

T1: 15 minutes preoperatively; T2: $30^{\text {th }}$ minute intraoperatively; T3: 30 minutes after administration of the reversing agent; T4: 2 hours after administration of the reversing agent; T5: 4 hours after administration of the reversing agent

SAP: Systolic arterial pressure; DAP: Diastolic arterial pressure; MAP: Mean arterial pressure; HR: Heart rate; N: Neostigmine; S: Sugammadex; SD: Standard deviation.

$* \mathrm{p}<0.05$ between the groups 
There are many factors that may influence blood glucose during and after a surgery. These factors include preoperative increased catabolic hormones due to dehydration, hunger, fear, perioperative bleeding, hypothermia, hypoxia, hypercapnia, pain, immobility, hypoxia, infection and circadian rhythm changes. The levels of adrenocorticotropic hormone and cortisol are elevated at the beginning of surgery, and then catecholamines, glucagon and growth hormone are released. Insulin secretion is reduced and insulin resistance often develops during surgical trauma $(12,13)$. Perioperative blood glucose level is elevated as a result of all of these reasons.

Sugammadex is the first selective neuromuscular relaxant drug binding agent, which is used to reverse the effects of non-depolarizing neuromuscular blockers. Decurarisation with sugammadex is a new approach to safely and rapidly reverse vecuronium or rocuronium-induced neuromuscular block. Sugammadex is a cyclodextrin and cyclodextrins contain 6-12 glucose units. Sugammadex does not bind to plasma proteins and erythrocytes. It does not produce any metabolite and is usually excreted unchanged with encapsulated neuromuscular blocker drug in urine within 24 hours. No major adverse effect of sugammadex was reported previously. Minor and common adverse effects reported include non-specific hypotension and cough at the end of the operation due to light anesthesia. Uncommon side effects are allergic reactions and return of muscle relaxation after the operation $(14,15,16)$.

We hypothesized blood glucose level might increase due to the presence of free sugammadex in plasma and we noted a significant increase compared to neostigmine shortly after drug administration and after withdrawal of the endotracheal tube. This can be explained in two ways: stress response such as reaction to the endotracheal tube, agitation due to fast awakening as a result of the rapid reversal effect of sugammadex may be the reason of high blood glucose levels when sugammadex was used. In accordance with the literature, we considered that increase in blood glucose at early postoperative phase was associated with fast and efficient decurarisation provided by sugammadex (16-19). The second reason can be addressed as blood glucose levels are elevated due to the chemical structure of sugammadex. We evaluated blood glucose levels at 2 and 4 hours after extubation to distinguish between the two reasons. The blood glucose levels were significantly higher at $30^{\text {th }}$ minute after extubation compared to glucose levels in the preoperative and intraoperative period in Sugammadex and Neostigmine groups. Thus, we considered increase of blood glucose at $30^{\text {th }}$ minute after extubation may be associated with early postoperative stress. However, the blood glucose levels were also significantly higher 2 and 4 hours after endotracheal extubation in sugammadex-treated patients. We concluded that this situation was associated with the chemical structure of sugammadex.

The effect of sugammadex on blood glucose levels was studied among diabetic rats previously (20). Sugammadex was administered at different doses to control rats and diabetic rats. Serum glucose levels were found significantly higher in diabetic rats however there was no difference between diabetic rats that sugammadex was not given and sugammadex-treated diabetic rats. The effect of sugammadex on serum glucose has not been fully understood as expected because sugammadex-treated rats were diabetic. It is noteworthy that, reversal of neuromuscular block using sugammadex showed no difference in diabetic patients versus general population (21).

In conclusion, blood glucose levels were higher after administration of sugammadex compared to neostigmine in acute post-operative period. We consider that sugammadex contains glucose molecules and does not bind to plasma proteins may cause an increase in blood glucose level and this increase may be associated with chemical structure of sugammadex rather than surgical stress of patients.

\section{DECLARATION OF INTEREST}

The authors declare that there are no conflicts of interests.

\section{Licensing}

This work is licensed under a Creative Commons Attribution 4.0 International (CC BY 4.0) License.

\section{Financial or grant support:}

None. 


\title{
Sažetak
}

\section{EFEKAT SUGAMADEKSA I NEOSTIGMINA NA NIVO GLUKOZE U KRVI: PROSPEKTIVNO RANDOMIZOVANO KONTROLISANO ISPITIVANJE}

\author{
Yazar Akif Mehmet, ${ }^{1}$ Balaban Onur, ${ }^{2}$ Yoldas Kuvvet Tuba, ${ }^{3}$ Sarıus Zehra ${ }^{4}$ \\ ${ }^{1}$ Konya Training and Research Hospital, Department of Anesthesiology, Konya, Turkey \\ 2 Dumlupinar University, Department of Anesthesiology \& Pain Medicine, Kutahya, Turkey \\ ${ }^{3}$ Ege University, Department of Anesthesiology, Izmir, Turkey \\ ${ }^{4}$ Nevsehir Public Hospital, Department of Anesthesiology, Nevsehir, Turkey
}

Uvod: Sugamadeks se koristi kao alternativa inhibitorima holinesteraze kod reverzibilnog neuromuskularnog bloka. Sugamadeks je molekul ciklodekstrina koji se sastoji od međusobno povezanih molekula šećera. Shodno hemijskoj strukturi, sugamadeks može povećati nivo glukoze u krvi. Cilj nam je bio da istražimo efekat sugamadeksa na nivo glukoze u krvi i uporedimo sugamadeks sa konvencionalnim neostigminom. Metode: Šezdeset pacijenata, podvrgnutih srednjeročnoj abdominalnoj operaciji pod opštom anestezijom, uključeno je u ovu studiju. Pacijenti su nasumično podeljeni u dve grupe: Grupa N ( $=30)$ i Grupa $S(n=30)$. Doza od $50 \mu \mathrm{g} / \mathrm{kg}$ neostigmina i $20 \mu \mathrm{g} / \mathrm{kg}$ atropina je data pacijentima iz Grupe N, a 2 mg/kg sugamadeksa je data pa-

\section{REFERENCES}

1. Warner DS, Gionet TX, Todd MM, Mc Allister AM. Insulin induced normoglycemia improves ischemic outcome in hyperglycemic rats. Stroke. 1992; 23 (12): 1775-81.

2. Schricker T, Lattermann R, Schreiber M, Geisser W, Georgieff M, Radermacher P. The hyperglycaemic response to surgery: pathophysiology, clinical implications and modification by the anaesthetic technique. Clinica Intensive Care. 1998; 9 (3): 118-28.

3. Kim YB, Sung TY, Yang HS. Factors that affect the onset of action of non-depolarizing neuromuscular blocking agents. Korean J Anesthesiol. 2017; 70(5): 500-10.

4. Paech MJ, Kaye R, Baber C, Nathan EA. Recovery characteristics of patients receiving either sugammadex or neostigmine and glycopyrrolate for reversal of neuromuscular block: a randomised controlled trial. Anaesthesia. 2017 Dec 7. [Epub ahead of print].

5. Tajaate N, Schreiber JU, Fuchs-Buder T, Jelting Y, Kranke P. Neostigmine-based reversal of intermediate acting neuromuscular blocking agents to prevent postoperative residual paralysis: A systematic review. Eur J Anaesthesiol 2017 Nov 20. [Epub ahead of print].

6. Gijsenbergh F, Ramael S, Houwing N, van Iersel T. First human exposure of Org 25969, a novel agent toreverse the action of rocuronium bromide. Anesthesiology. 2005; 103(4): 695-703.

7. Sorgenfrei IF, Norrild K, Larsen PB, Stensballe J, Ostergaard D, Prins ME, et al. Reversal of rocuronium-induced neuromuscular block by the selective relaxant binding agent sugammadex: a dose-finding and safety study. Anesthesiology. 2006; 104(4): 667-74. cijentima iz Grupe S. Nivo glukoze u krvi meren je 15 minuta pre (T1) i 30og minuta operacije (T2). Nivo glukoze u krvi je takođe merena 30 minuta (T3), 2h (T4) i 4h (T5) posle administracije reverzibilnog agensa.

Rezultati: Nivoi glukoze u krvi mereni u vremenu T3, T4, T5 su bili značajno viši u Grupi S u poređenju sa Grupom N $(p<0.05)$. Smatramo da sugamadeks koji sadrži molekule glukoze i ne vezuje se za proteine plazme, može izazvati povećanje nivoa glukoze u krvi i ovo povećanje može biti povezano sa hemijskom strukturom sugamadeksa pre nego sa operacijom izazvanim stresom pacijenata.

Ključne reči: reverzibilni neuromuskularni blok, sugamadeks, neostigmin, nivo glukoze u krvi.

8. de Boer HD, van Egmond J, van de Pol F, Bom A, Booij LH. Chemical encapsulation of rocuronium by synthetic cyclodextrin derivatives: reversal of neuromuscular block in anaesthetized Rhesus monkeys. Br J Anaesth. 2006; 96(2): 201-6.

9. Caldwell JE, Miller RD. Clinical implications of sugammadex. Anaesthesia. 2009; 64 (Suppl 1): 66-72.

10. Harada A. 2001. Cyclodextrin-based molecular machines. Acc Chem Res. 2001; 34(6): 456-64.

11. Hristovska AM, Duch P, Allingstrup M, Afshari A. Efficacy and safety of sugammadex versus neostigmine in reversing neuromuscular blockade in adults. Cochrane Database Syst Rev. 2017; 8: CD012763.

12. Allison SP, Tomlin PJ, Chamberlain MJ. Some effects of anaesthesia and surgery on carbohydrate and fat metabolism. Br J Anaesth. 1998; 81(2): 273-7.

13. Carson J, Scholz PM, Chen AY, Peterson FD, Gold J, Schneider SH. Diabetes mellitus increases short-term mortality and morbidity in patients undergoing coronary artery bypass graft surgery. J Am Coll Cardiol. 2002; 40(3): 418-23.

14. Crini G, Morcellet M. Synthesis and applications of adsorbents containing cyclodextrins. J Sep Sci. 2002; 25(13):789-813.

15. Shields M, Giovannelli M, Mirakhur RK, Moppett I, Adams J, Hermens Y. Org 25969 (sugammadex), a selective relaxant binding agent for antagonism of prolonged rocuronium-induced neuromuscular block. Br J Anaesth. 2006; 96(1): 36-43.

16. Summary of product characteristics (Sugammadex) https://ec.europa.eu/health/documents/communityregister/2016/20160226134295/anx_134295_en.pdf.

17. Suy K, Morias K, Cammu G, Hans P, van Duijnhoven WG, Heeringa $\mathrm{M}$, et al. Effective reversal of moderate rocuroni- 
um- or vecuronium-induced neuromuscular block with sugammadex, a selective relaxant binding agent. Anesthesiology. 2007; 106(2): 283-8.

18. Blobner M, Eriksson L, Scholz J, Hillebrand H, Pompei L. Reversal of rocuronium- induced neuromuscular blockade with sugammadex compared with neostigmine during sevoflurane anaesthesia: results of a randomised, controlledtrial. Eur J Anaesthesiol. 2010; 27(10): 87481.

19. Jones RK, Caldwell JE, Brull SJ, Soto RG. Reversal of proufond rocuronium induced blockade with sugammadex a randomized comparison with neostigmine. Anesthesiology. 2008; 109(5): 816-24.

20. Kiraz HA, Turgut HC, Kartal S, Comu FM, Kip G, Alkan M, et al. Effect of low and high dose sugammadex on erythrocyte deformability in streptozotocin-induced diabetic rats. Gazi Med J 2015; 26(3): 107-9. kontrila zakazan.

21. Ignacio AB, Felix LS, Luciano AC, Diego DZ, Andrees GL, Enrique FJ. Neuromuscular block reversal with sugammadex in type 2 diabetic patients. Perioperative Care and Operating Room Management 2015; (1)1: 13-18.

\section{Correspondence to/Autor za korespondenciju}

Mehmet Akif Yazar M.D.

Department of Anesthesiology

Adress: Konya Training and Research Hospital, Department of Anesthesiology, Konya, Turkey.

Phone: +90 3842285050

Mobil Phone: +90 5055665758

E-mail: makifyazar@hotmail.com 